\title{
Rhodococcus equi: are phenotypic tests the best method for accurate identification?
}

\author{
Mehdi Fatahi Bafghi ${ }^{1}$
}

Received: 11 June 2015 / Accepted: 4 August 2015 / Published online: 9 August 2015

(C) Springer-Verlag London 2015

Heidari Sureshjani and colleagues recently reported Isolation of Rhodococcus equi from a mule with cutaneous wound (Sureshjani et al. 2014). In this article, they describe the use of phenotypic testing for identification of species. The genus Rhodococcus is one of the actinomycete families and the name of this genus first used by Zopf. Rhodococcus are Gram-positive, partially acid fast, aerobic, and non-motile bacteria (Bell et al. 1998). Identification of Rhodococcus species using conventional methods is difficult, and the results of these methods are not suitable for accurate identification. There is some published evidence that the identification of Rhodococcus and Gordonia from each other is impossible with phenotypic tests (Blanc et al. 2007). CAMP (Christie-Atkins-Munch-Petersen) test is actually a rapid identification phenotypic marker for $R$. equi, although this test is also positive in other bacteria such as Rhodococcus erythropolis, Rhodococcus rhodochrous, Dietzia spp., and Mycobacterium spp. (Pd et al. 2012). The use of conventional methods with molecular technique such as polymerase chain reaction (using choE gene) is very important and necessary for accurate identification of $R$. equi (Pd et al. 2012; Krewer et al. 2008; Ladrón et al. 2003).

\section{References}

Bell K, Philp J, Aw D, Christofi N (1998) The genus Rhodococcus. J Appl Microbiol 85(2):195-210

Blanc V, Dalle M, Markarian A, Debunne M, Duplay E, Rodriguez-Nava V et al (2007) Gordonia terrae: a difficultto-diagnose emerging pathogen? J Clin Microbiol 45(3): 1076-1077

Krewer CC, Spricigo DA, Botton SA, Costa MMD, Schrank I, Vargas ACD (2008) Molecular characterization of Rhodococcus equi isolates of horse breeding farms from an endemic region in south of Brazil by multiplex PCR. Braz J Microbiol 39(1):188-193

Ladrón N, Fernández M, Agüero J, Zörn BG, Vázquez-Boland JA, Navas J (2003) Rapid identification of Rhodococcus equi by a PCR assay targeting the $c h o E$ gene. J Clin Microbiol 41(7):3241-3245

Silva P, Santos ACB, Sato DN, Silva JO, Medeiros MIC, Carneiro AMM et al (2012) Phenotypic and genotypic characterization of Rhodococcus equi isolated from sputum. Braz J Infect Dis 16(5): 409-415

Sureshjani MH, Atyabi N, Tazikeh A, Falahatipour SK, Hashemian M (2014) Isolation of Rhodococcus equi from a mule with cutaneous wound. Comp Clin Pathol 24(3): $691-693$

Mehdi Fatahi Bafghi

mehdifatahi371@gmail.com

1 Department of Pathobiology, School of Public Health, Tehran University of Medical Sciences, Tehran, Iran 